\title{
Bone-seeking TRAP conjugates: surprising observations and their implications on the development of gallium-68-labeled bisphosphonates
}

\author{
Johannes Notni ${ }^{1 *}$, Jan Plutnar ${ }^{2}$ and Hans-Jürgen Wester ${ }^{1}$
}

\begin{abstract}
Background: Bisphosphonates possess strong affinity to bone. ${ }^{99 \mathrm{~m}} \mathrm{Tc}$ bisphosphonate complexes are widely used for bone scintigraphy. For positron emission tomography (PET) bone imaging, Ga-68-based PET tracers based on bisphosphonates are highly desirable.

Findings: Two trimeric bisphosphonate conjugates of the triazacyclononane-phosphinate (TRAP) chelator were synthesized, labeled with Ga-68, and used for microPET imaging of bone in male Lewis rats. Both Ga-68 tracers show bone uptake and, thus, are suitable for PET bone imaging. Surprisingly, Ga-71 nuclear magnetic resonance data prove that $\mathrm{Ga}(\mathrm{III})$ is not located in the chelating cavity of TRAP and must therefore be bound by the conjugated bisphosphonate units.

Conclusion: The intrinsic Ga-68 chelating properties of TRAP are not needed for Ga-68 PET bone imaging with TRAP-bisphosphonate conjugates. Here, TRAP serves only as a trimeric scaffold. For preparation of Ga-68-based bone seekers for PET, it appears sufficient to equip branched scaffolds with multiple bisphosphonate units, which serve both Ga-68-binding and bone-targeting purposes.
\end{abstract}

Keywords: Gallium-68, Bisphosphonates, Positron emission tomography, Bone seekers, MicroPET, Bone imaging

\section{Background}

Geminal bisphosphonates possess strong affinity to bone $[1,2]$. In living organisms, administration of bisphosphonates leads to inhibition of osteoclasts (bone resorbing cells), which results in a lower rate of bone resorption $[3,4]$. Therapy with bisphosphonate drugs is thus performed to prevent decrease of bone density caused by osteogenesis imperfecta (brittle bone disease) [5] or osteoporosis $[3,6]$. In addition, bisphosphonate complexes of ${ }^{99 \mathrm{~m}} \mathrm{Tc}$ (e.g., of medronic acid, ${ }^{~} 99 \mathrm{~m} \mathrm{Tc}-\mathrm{MDP}$; see Figure 1) are the mainstay of bone imaging by scintigraphy and SPECT. However, as positron emission tomography (PET) offers higher resolution and sensitivity, PET bone-imaging agents are of high interest. Direct

\footnotetext{
* Correspondence: johannes.notni@tum.de

'Pharmaceutical Radiochemistry, Technische Universität München, WaltherMeissner-Str. 3, Garching 85748, Germany

Full list of author information is available at the end of the article
}

utilization of the $\beta^{+}$-emitting radionuclide ${ }^{18} \mathrm{~F}\left(t_{1 / 2}=\right.$ $\left.110 \mathrm{~min}, E_{\max , \beta+}=634 \mathrm{keV}\right)$ is the most simple and straightforward approach because $\left[{ }^{18} \mathrm{~F}\right]$ fluoride ${ }^{18} \mathrm{~F}^{-}$ inherently possesses a high affinity to bone. However, ${ }^{18}$ $\mathrm{F}$ is cyclotron-produced, and therefore, a full geographical coverage, comparable to the supply of generator-produced ${ }^{99 \mathrm{~m}} \mathrm{Tc}$, cannot be guaranteed. Thus, bisphosphonate mono-conjugates of the currently most popular radiometal chelators 1,4,7,10-tetraazacyclododecane-tetraacetic acid [7-9] and 1,4,7-triazacyclononanetriacetic acid [10] have been prepared to utilize generator-produced ${ }^{68} \mathrm{Ga}\left(t_{1 / 2}=68 \mathrm{~min}, E_{\max , \beta+}=1.9 \mathrm{MeV}\right)$ for PET bone imaging. Advancing this approach, this pilot study describes preclinical PET imaging results for trimeric bisphosphonate conjugates of the recently introduced chelator triazacyclononane-phosphinate (TRAP) (see Figure 2) [11-13]. 


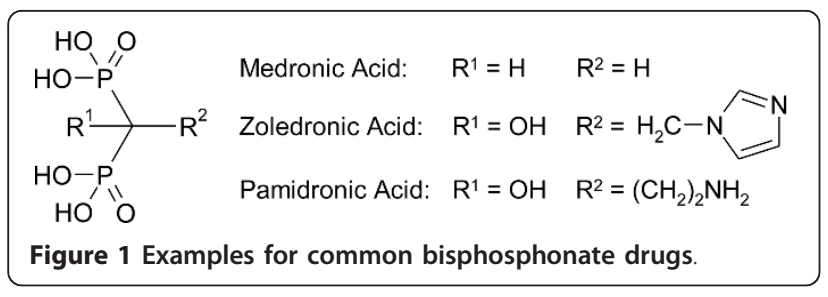

\section{Methods}

General procedures and instrumentation (nuclear magnetic resonance (NMR), electrospray mass spectroscopy (ESI-MS), ultrafiltration/diafiltration, PET) have been described before [13]. [ ${ }^{18} \mathrm{~F}$ ]fluoride formulation for injection was prepared by adding $100 \mathrm{MBq}$ of ${ }^{18} \mathrm{~F}$ (obtained from routine cyclotron production at Klinikum rechts der Isar, Technische Universität München, München, Germany) to phosphate buffered saline (PBS) (1 mL).

Synthesis of bisphosphonate conjugates (Figure 2): TRAP. $2 \mathrm{H}_{2} \mathrm{O}(0.3 \mathrm{mmol}, 185 \mathrm{mg})$, diisopropylethylamide ( $3 \mathrm{mmol}, 388 \mathrm{mg}, 510 \mu \mathrm{L}$ ), and the amino-bisphosphonate $(1.5 \mathrm{mmol})$; for TRAP $(\mathrm{MDP})_{3}$, tetraethyl(aminomethylene)bisphosphonate $455 \mathrm{mg}$; and for TRAP(PDP) 3 , tetraethyl(1-aminopropylene)bisphosphonate $500 \mathrm{mg}$, were dissolved in DMSO (2 mL). Then, HATU (2.4 mmol, $921 \mathrm{mg}$ ) was added with stirring. After $25 \mathrm{~min}$, the reaction mixture was diluted with water $(50 \mathrm{~mL})$ and subjected to diafiltration (membrane with $500 \mathrm{Da}$ MWCO). After $250 \mathrm{~mL}$ of water had passed, the cell content was concentrated in vacuo and subjected to preparative HPLC (column: YMC C18 ec $250 \times 30 \mathrm{~mm}$; detection wavelength, $220 \mathrm{~nm}$; eluent $\mathrm{A}, \mathrm{MeCN}$ with $0.1 \%$ TFA; eluent $\mathrm{B}$, water with $0.1 \%$ TFA; gradient $25 \%$ to $50 \% \mathrm{~B}$ in $20 \mathrm{~min}, t_{\mathrm{R}}\left(\right.$ dodecaethyl-TRAP $\left.(\mathrm{MDP})_{3}\right)=12$ min, $t_{\mathrm{R}}$ (dodecaethyl-TRAP $\left.\left.(\mathrm{PDP})_{3}\right)=16 \mathrm{~min}\right)$. After evaporation of the solvents, the remaining viscous oil was dissolved in $\mathrm{HBr} /$ glacial acetic acid (33\%) and stirred for 3 days. Addition of methanol to the reaction mixture yielded the products as colorless, crystalline solids. Data for TRAP(MDP) $)_{3}$ : yield $201 \mathrm{mg}(61 \%) ; \mathrm{MW}$ (calculated for $\mathrm{C}_{21} \mathrm{H}_{51} \mathrm{~N}_{6} \mathrm{O}_{27} \mathrm{P}_{9}$ ) 1,098.43; ESI-MS negative $\mathrm{m} / z=$ $1,097\left(\mathrm{M}-\mathrm{H}^{+}\right)$and $548\left(\mathrm{M}-2 \mathrm{H}^{+}\right) ;{ }^{1} \mathrm{H}$ NMR $(600 \mathrm{MHz}$, $\left.\mathrm{D}_{2} \mathrm{O}\right) \delta=2.13(\mathrm{~m}, 6 \mathrm{H}), 2.67(\mathrm{~m}, 6 \mathrm{H}), 3.48\left(\mathrm{~d},{ }^{3} J_{\mathrm{HH}}=\right.$
$5.4 \mathrm{~Hz}, 6 \mathrm{H}), 3.56(\mathrm{~s}$, broad, $12 \mathrm{H})$, and $4.71\left(\mathrm{t}, J_{\mathrm{PH}}=\right.$ $21.3 \mathrm{~Hz}, 3 \mathrm{H}) \mathrm{ppm}^{13} \mathrm{C}$ NMR $\left(151 \mathrm{MHz}, \mathrm{D}_{2} \mathrm{O}\right) \delta=$ $26.11\left(\mathrm{~d},{ }^{1} J_{\mathrm{PC}}=93.18 \mathrm{~Hz}\right), 28.65,52.13,54.74\left(\mathrm{~d},{ }^{1} J_{\mathrm{PC}}=\right.$ $89.07 \mathrm{~Hz}), 47.45\left(\mathrm{t},{ }^{1} J_{\mathrm{PC}}=139.28 \mathrm{~Hz}\right)$, and $174.54(\mathrm{dt}$, ${ }^{2} J_{\mathrm{PC}}=12.28$ and $\left.{ }^{3} J_{\mathrm{PC}}=4.34 \mathrm{~Hz}\right) \mathrm{ppm}$; and ${ }^{31} \mathrm{P} \mathrm{NMR}$ $\left(121 \mathrm{MHz}, \mathrm{D}_{2} \mathrm{O}\right) \delta=14.10\left(\mathrm{~d},{ }^{2} J_{\mathrm{PP}}=15.7 \mathrm{~Hz}\right)$ and 39.90 ppm. Data for TRAP(PDP) 3 : yield $195 \mathrm{mg}$ (55\%); MW (calculated for $\mathrm{C}_{27} \mathrm{H}_{63} \mathrm{~N}_{6} \mathrm{O}_{27} \mathrm{P}_{9}$ ) 1,182.59; ESI-MS negative $m / z=1,181\left(\mathrm{M}-\mathrm{H}^{+}\right), 590\left(\mathrm{M}-2 \mathrm{H}^{+}\right)$, and $393(\mathrm{M}-3$ $\left.\mathrm{H}^{+}\right) ;{ }^{1} \mathrm{H}$ NMR $\left(600 \mathrm{MHz}, \mathrm{D}_{2} \mathrm{O}\right) \delta=2.07(\mathrm{~m}, 6 \mathrm{H}), 2.10$ $(\mathrm{m}, 6 \mathrm{H}), 2.36\left(\mathrm{tt}, J_{\mathrm{PH}}=23.52 \mathrm{~Hz},{ }^{3} J_{\mathrm{HH}}=5.97 \mathrm{~Hz}, 3 \mathrm{H}\right)$, $2.53(\mathrm{~m}, 6 \mathrm{H}), 3.44\left(\mathrm{t},{ }^{3} J_{\mathrm{HH}}=6.3 \mathrm{~Hz}, 6 \mathrm{H}\right), 3.45(\mathrm{t}$, broad, $\left.{ }^{3} J_{\mathrm{HH}}=6.6 \mathrm{~Hz}\right)$, and $3.52(\mathrm{~s}$, broad, $12 \mathrm{H}) \mathrm{ppm} ;{ }^{13}$ C NMR (151 MHz, D $2 \mathrm{O}) \delta=25.36\left(\mathrm{t},{ }^{2} J_{\mathrm{PC}}=4.2 \mathrm{~Hz}\right)$, $26.29\left(\mathrm{~d},{ }^{1} J_{\mathrm{PC}}=93.5 \mathrm{~Hz}\right), 28.63\left(\mathrm{~d},{ }^{2} J_{\mathrm{PC}}=3.9 \mathrm{~Hz}\right), 35.77$ $\left(\mathrm{t},{ }^{1} J_{\mathrm{PC}}=128.5 \mathrm{~Hz}\right), 39.48\left(\mathrm{~d},{ }^{3} J_{\mathrm{PC}}=7.4 \mathrm{~Hz}\right), 52.14$, $54.82\left(\mathrm{~d},{ }^{1} J_{\mathrm{PC}}=88.6 \mathrm{~Hz}\right)$, and $175.41\left(\mathrm{~d},{ }^{3} J_{\mathrm{PC}}=13.1 \mathrm{~Hz}\right)$ ppm; and ${ }^{31} \mathrm{P}$ NMR $\left(121 \mathrm{MHz}, \mathrm{D}_{2} \mathrm{O}\right) \delta=21.53\left(\mathrm{~d},{ }^{2} J_{\mathrm{PP}}\right.$ $=15.5 \mathrm{~Hz}$ ) and $39.69 \mathrm{ppm}$.

${ }^{68} \mathrm{Ga}$ for labeling was obtained from a $\mathrm{SnO}_{2}$-based ${ }^{68} \mathrm{Ge} /{ }^{68} \mathrm{Ga}$ generator (iThemba LABS, Somerset West, South Africa), eluted with 1.0 M HCl. A $1.25 \mathrm{~mL}$ fraction of the eluate containing $c a .80 \%$ of the total activity ( $c a$. $1.3 \mathrm{GBq}$ ) was adjusted to $\mathrm{pH} 3.3$ by adding a solution of 600 mg 2-[4-(2-hydroxyethyl)-1-piperazinyl]-ethanesulfonic acid (HEPES) in $0.5 \mathrm{~mL}$ water. To a $90 \mu \mathrm{L}$ aliquot of this mixture, $10 \mu \mathrm{L}$ of $10^{-4} \mathrm{M}$ stock solution of the ligand was added. After heating for $5 \mathrm{~min}$ to $95^{\circ} \mathrm{C}$, the solution was passed over a cation exchanger SPE cartridge (Chromafix HR-XC M, Macherey-Nagel, Düren, Germany) and purged with water $(1 \mathrm{~mL})$. This procedure removed noncomplexed ${ }^{68} \mathrm{Ga}$ as well as HEPES, which was confirmed by processing of blank samples. Radiochemical yields, determined by measuring the activity on the cartridge and in the eluate, were $>85 \%$. Formulation was done by adjusting the $\mathrm{pH}$ of the eluate to 7.4 by adding approximately $50 \mu \mathrm{L}$ of a solution of $\mathrm{NaOH}(1 \mathrm{~g})$ and $\mathrm{NaH}_{2} \mathrm{PO}_{4}$ $(483 \mathrm{mg})$ in water $(20 \mathrm{~mL})$ while monitoring the $\mathrm{pH}$ with a pH meter. 'Free' ${ }^{68}$ Ga formulation was prepared by addition of the generator eluate $(40 \mu \mathrm{L}$, ca. $50 \mathrm{MBq})$ to PBS (1 mL), resulting in $\mathrm{pH} 7.2$.

All animal experiments were carried out in accordance with the current animal welfare regulations in Germany.
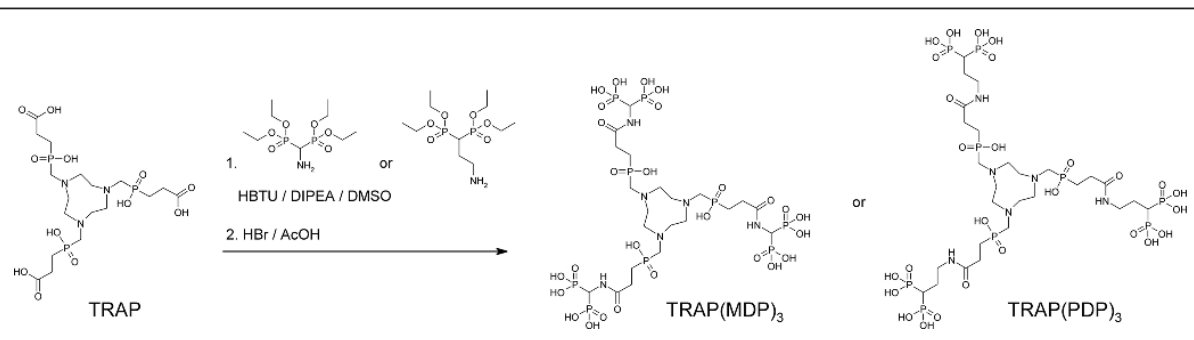

Figure 2 Synthesis of trimeric TRAP-bisphosphonate conjugates TRAP(MDP) ${ }_{3}$ and TRAP(PDP) $)_{3}$ 
Five male Lewis rats (age 7 weeks, ca. 200 g) were kept under standard laboratory conditions (12 h light/12 h dark) and given standard diet and water ad libitum. For PET, ca. $35 \mathrm{MBq}$ of tracer was injected into the tail vein under isoflurane anesthesia. Two subsequent scans of 15 min were recorded 60 min post injection, using two different axial bed positions in order to image the entire animals. Images were reconstructed using a OSEM3D algorithm without scatter and attenuation correction. For each full-body maximum intensity projection (MIP), two part-body MIPs were stitched together manually using graphics software. PET images are from representative animals reflecting the group.

\section{Results and discussion}

Figure 3 shows that free ${ }^{68} \mathrm{Ga}$ (III) (we use this generalized term since ${ }^{68} \mathrm{Ga}$ species in PBS solutions are not well defined) provides almost no contrast of the skeleton over other tissues, as intravenous injection of free ${ }^{68} \mathrm{Ga}$ (III) predominantly results in transferrin-bound activity [14-17]. In contrast, both bisphosphonate tracers ${ }^{68} \mathrm{Ga}$ TRAP(MDP $)_{3}$ and ${ }^{68}$ Ga-TRAP(PDP) $)_{3}$ bind to bone while showing low levels in blood and soft tissues. Apparently, PET image quality achieved therewith cannot compete with that of $\left[{ }^{18} \mathrm{~F}\right]$ fluoride. ${ }^{18} \mathrm{~F}$ possesses a lower positron energy than ${ }^{68} \mathrm{Ga}$, resulting in lower tissue penetration (FW20H of $0.54 \mathrm{~mm}$ and $2.12 \mathrm{~mm}$ in soft tissue for ${ }^{18} \mathrm{~F}$ and ${ }^{68} \mathrm{Ga}$, respectively [18]), and therefore in a lower degree of image blurring. However, as the difference in resolution for a clinical 3-mm PET camera is small (3.05 $\mathrm{mm}$ for ${ }^{18} \mathrm{~F}$ and $3.57 \mathrm{~mm}$ for ${ }^{68}$ $\mathrm{Ga}$ [18]), a successful application of ${ }^{68} \mathrm{Ga}$ bone-imaging agents in patients is not precluded.

Upon investigation of the mode of gallium binding, we found that an equimolar mixture of ${ }^{69,71} \mathrm{Ga}^{3+}$ and either ${ }^{68} \mathrm{Ga}$-TRAP(MDP) $)_{3}$ or ${ }^{68}$ Ga-TRAP(PDP) $)_{3}$ does not yield any signal in ${ }^{71}$ Ga NMR spectra, not even after heating to $95^{\circ} \mathrm{C}$ for hours. However, the octahedral $\mathrm{N}_{3} \mathrm{O}_{3}$ coordination usually found for 'in-cage' $\mathrm{Ga}$ (III) complexes of TRAP ligands generally yields sharp ${ }^{71} \mathrm{Ga}$ NMR resonances at $\delta=130$ to $142 \mathrm{ppm}[11,12]$. Obviously, Ga(III) ion is not located in the TRAP cavity and, therefore, must be complexed in an 'out-of-cage' manner by the bisphosphonate groups. Although this result is quite unexpected, PET images nevertheless prove that the degree of kinetic stability of these complexes is sufficiently high to carry ${ }^{68} \mathrm{Ga}$ to the bone and retain it there. However, Figure 3 also shows a slightly higher background uptake for ${ }^{68}$ Ga-TRAP(MDP) $)_{3}$, most likely caused by partial decomplexation in vivo due to lower complex stability. Clearance of both ${ }^{68}$ Ga tracers occurred faster than ${ }^{18} \mathrm{~F}^{-}$and exclusively via the kidneys.

\section{Conclusion}

68 Ga-labeled trimeric bisphosphonate conjugates of TRAP were successfully applied for bone imaging in rats. Surprisingly, ${ }^{71}$ Ga NMR investigation revealed that $\mathrm{Ga}(\mathrm{III})$ ion is not located in the macrocyclic cavity of TRAP and, therefore, must be complexed by one or

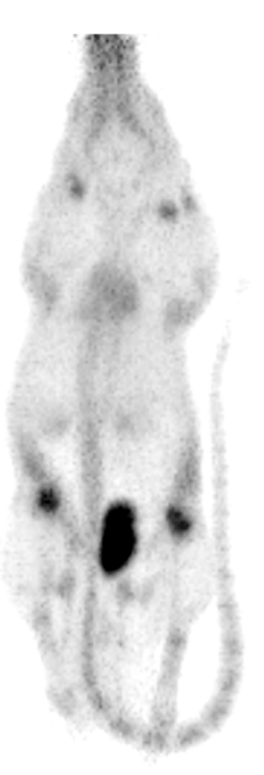

A

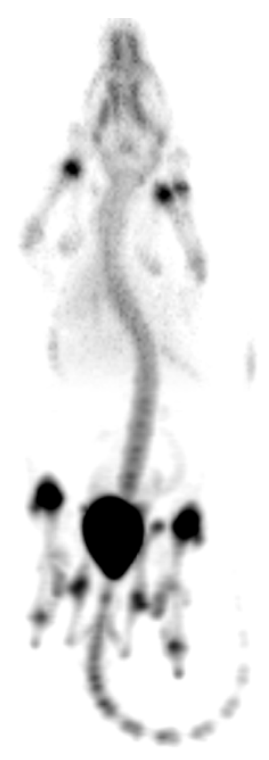

B

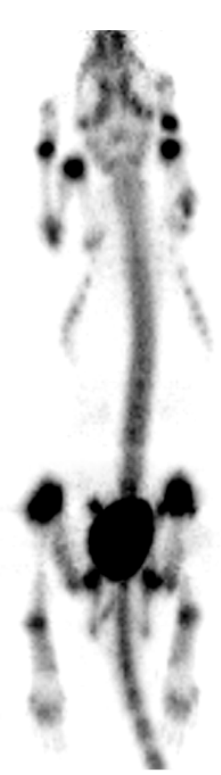

C

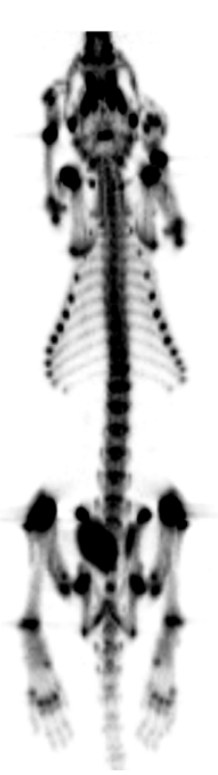

D

Figure 3 PET scans (MIP, 60 min p.i.) of Lewis rats using different tracers. (A) Free ${ }^{68} \mathrm{Ga}(I I I),\left(\right.$ B) ${ }^{68} \mathrm{Ga}-\mathrm{TRAP}(\mathrm{MDP})_{3},(\mathbf{C}){ }^{68} \mathrm{Ga}-\mathrm{TRAP}(\mathrm{PDP})_{3}$, and (D) ${ }^{18}$ F]fluoride. 
more side chain bisphosphonates. Although the primary chelation site of TRAP possesses excellent $\mathrm{Ga}$ (III) complexing properties [12], it apparently cannot compete with the bisphosphonates. In ${ }^{68} \mathrm{Ga}-\mathrm{TRAP}(\mathrm{MDP})_{3}$ and ${ }^{68}$ Ga-TRAP(PDP $)_{3}$, TRAP thus merely serves as a scaffold, and its ability for ${ }^{68} \mathrm{Ga}$ binding is not required. We therefore conclude that in designing bisphosphonate tracers for ${ }^{68} \mathrm{Ga}$-based PET bone imaging, the introduction of chelating moieties other than the bisphosphonates themselves might be unnecessary. Rather, it appears to be sufficient to equip suitable branched scaffolds with multiple bisphosphonate units which serve both ${ }^{68} \mathrm{Ga}$ binding and bone-targeting purposes.

\section{Abbreviations}

ESI-MS: electrospray mass spectroscopy; HEPES: 2-[4-(2-hydroxyethyl)-1piperazinyl]-ethanesulfonic acid; MIP: maximum intensity projection; NMR: nuclear magnetic resonance; PBS: phosphate buffered saline; PET: positron emission tomography; TRAP: triazacyclononane-phosphinate.

\section{Acknowledgements}

The authors thank E. Weidl for the animal handling, and Sibylle Reder, Marco Lehmann, and Markus Mittelhäuser for the assistance with PET imaging.

\section{Author details}

${ }^{1}$ Pharmaceutical Radiochemistry, Technische Universität München, WaltherMeissner-Str. 3, Garching 85748, Germany ${ }^{2}$ Department of Inorganic Chemistry, Faculty of Science, Charles University in Prague, Hlavova 2030, Prague 2 12843, Czech Republic

\section{Authors' contributions}

JN developed the study concept; performed synthesis, radiolabeling, PET imaging, and PET data analysis; and wrote the manuscript. JP performed all NMR measurements and evaluated the data. HJW provided important advice in the conception of the study, gave advice in the interpretation of the data and critically reviewed the manuscript. All authors read and approved the final manuscript.

\section{Competing interests}

The authors declare that they have no competing interests.

Received: 6 February 2012 Accepted: 30 March 2012

Published: 30 March 2012

\section{References}

1. Mukherjee S, Huang C, Guerra F, Wang K, Oldfield E: Thermodynamics of bisphosphonates binding to human bone: a two-site model. J Am Chem Soc 2009, 131:8375-8376

2. Mukherjee S, Song Y, Oldfield E: NMR investigations of the static and dynamic structures of bisphosphonates on human bone: a molecular model. J Am Chem Soc 2008, 130:1264-1273.

3. Ebetino FH, Hogan AML, Sun ST, Tsoumpra MK, Duan XC, Triffitt JT, Kwaasi AA, Dunford JE, Barnett BL, Oppermann U, Lundy MW, Boyde A, Kashemirov BA, McKenna CE, Russell RGG: The relationship between the chemistry and biological activity of the bisphosphonates. Bone 2011, 49:20-33.

4. Roelofs AJ, Thompson K, Ebetino FH, Rogers MJ, Coxon FP: Bisphosphonates: molecular mechanisms of action and effects on bone cells, monocytes and macrophages. Curr Pharm Design 2010, 16:2950-2960.

5. Shapiro JR, Sponsellor PD: Osteogenesis imperfecta: questions and answers. Curr Opin Pediatr 2010, 21:709-716.

6. Le Goff B, Guillot P, Glemarec J, Berthelot JM, Maugars Y: A comparison between bisphosphonates and other treatments for osteoporosis. Curr Pharm Design 2010, 16:3037-3044.
7. Kubíček V, Rudovský J, Kotek J, Hermann P: Vander Elst L, Muller RN, Kolar ZI, Wolterbeek HT, Peters JA, Lukeš I: A bisphosphonate monoamide analogue of DOTA: a potential agent for bone targeting. J Am Chem SoC 2005, 127:16477-16485.

8. Vitha T, Kubíček V, Hermann P: Vander Elst L, Muller RN, Kolar ZI, Wolterbeek HT, Breeman WAP, Lukeš I, Peters JA: Lanthanide(III) complexes of bis(phosphonate) monoamide analogues of DOTA: boneseeking agents for imaging and therapy. J Med Chem 2008, 51:677-683.

9. Fellner M, Baum RP, Kubíček V, Hermann P, Lukeš I, Prasad V, Rösch F: PET/ CT imaging of osteoblastic bone metastases with $68 \mathrm{Ga}$ bisphosphonates: first human study. Eur J Nucl Med Mol Imaging 2010, 37:834.

10. Suzuki K, Satake M, Suwada J, Oshikiri S, Ashino H, Dozono H, Hino A, Kasahara H, Minamizawa T: Synthesis and evaluation of a novel $68 \mathrm{Ga}$ chelate-conjugated bisphosphonate as a bone-seeking agent for PET imaging. Nucl Med Biol 2011, 38:1011-1018.

11. Notni J, Hermann P, Havličcková J, Kotek J, Kubíček V, Plutnar J, Loktionova N, Riss PJ, Rösch F, Lukeš I: A triazacyclononane-based bifunctional phosphinate ligand for the preparation of multimeric $68 \mathrm{Ga}$ tracers for positron emission tomography. Chem Eur J 2010, 16:7174-7185.

12. Šimeček J, Schulz M, Notni J, Plutnar J, Kubíček V, Havlíčková J, Hermann P: Complexation of metal ions with TRAP (1,4,7-triazacyclononane phosphinic acid) ligands and NOTA: phosphinate-containing ligands as unique chelators for trivalent gallium. Inorg Chem 2012, 51:577-590.

13. Notni J, Šimeček J, Hermann P, Wester HJ: TRAP, a powerful and versatile framework for gallium-68 radiopharmaceuticals. Chem Eur J 2011, 17:14718-14722.

14. Clausen J, Edeling CJ, Fogh J: 67 Ga binding to human serum proteins and tumor components. Cancer Res 1974, 34:1931-1937.

15. Chikh Z, Ha-Duong NT, Miquel G: El Hage Chahine JM: Gallium uptake by transferrin and interaction with receptor 1. J Biol Inorg Chem 2007, $12: 90-100$

16. Otsuki $H$, Brunetti A, Owens ES, Finn RD, Blasberg RG: Comparison of iron59, indium-111, and gallium-69 transferrin as a macromolecular tracer of vascular permeability and the transferrin receptor. J Nucl Med 1989, 10:1676-1685.

17. Bernstein LR: Mechanisms of therapeutic activity for gallium. Pharmacol Rev 1998, 50:665-682

18. Sánchez-Crespo A, Andreo P, Larsson SA: Positron flight in human tissues and its influence on PET image spatial resolution. Eur J Nucl Med Mol Imaging 2004, 31:44-51.

doi:10.1186/2191-219X-2-13

Cite this article as: Notni et al:: Bone-seeking TRAP conjugates: surprising observations and their implications on the development of gallium-68-labeled bisphosphonates. EJNMMI Research 2012 2:13.

\section{Submit your manuscript to a SpringerOpen ${ }^{\mathcal{O}}$ journal and benefit from:}

- Convenient online submission

- Rigorous peer review

- Immediate publication on acceptance

- Open access: articles freely available online

- High visibility within the field

- Retaining the copyright to your article

Submit your next manuscript at $>$ springeropen.com 